\title{
Title:
}

\section{Unexplained ascites caused by myeloid sarcoma with omentum involvement}

\section{Authors:}

Yong Li, Jianfeng Pan, Xiaowei Liu

DOI: $10.17235 /$ reed.2021.7892/2021

Link: PubMed (Epub ahead of print)

Please cite this article as:

Li Yong, Pan Jianfeng, Liu Xiaowei. Unexplained ascites caused by myeloid sarcoma with omentum involvement. Rev Esp Enferm Dig 2021. doi: 10.17235/reed.2021.7892/2021.

This is a PDF file of an unedited manuscript that has been accepted for publication. As a service to our customers we are providing this early version of the manuscript. The manuscript will undergo copyediting, typesetting, and review of the resulting proof before it is published in its final form. Please note that during the production process errors may be discovered which could affect the content, and all legal disclaimers that apply to the journal pertain. 


\section{7892}

\section{Unexplained ascites caused by myeloid sarcoma with omentum involvement}

Yong Li, MD, Jianfeng Pan, MD, Xiaowei Liu, MD, PhD

${ }^{1}$ Department of Gastroenterology, Xiangya Hospital, Central South University, Changsha, China

Correspondence: Xiaowei Liu, Department of Gastroenterology, Xiangya Hospital, Central South University, Changsha, Hunan, China. E-mail: liuxw@csu.edu.cn

\section{Keywords}

Unexplained ascites, Myeloid sarcoma, Omentum

\section{Dear Editor,}

A previously healthy 40 -year-old male was admitted with a 10-day history of abdominal distension. Physical examinations revealed bulging flanks with a fluid wave and positive shifting dullness signs. Ultrasound revealed a thickening of the omentum with a thickness of $22 \mathrm{~mm}$ (Figure $1 \mathrm{~A}$ ), of which ultrasound-guided biopsies (Figure 1B) and immunohistochemistry revealing MPO (+), CD43 (+) were indicated myeloid sarcoma (MS). Surprisingly, both bone marrow biopsies and peripheral blood were normal in this patient. Finally, he was diagnosed as isolated MS and underwent induction chemotherapy [daunorubicin $90 \mathrm{mg} / \mathrm{m}^{2}$ (D1-D3) and cytosine arabinoside $100 \mathrm{mg} / \mathrm{m}^{2}$ twice daily (D1-D7)]. Unfortunately, he died of pneumonia due to immunodeficiency after chemotherapy 2 months later.

\section{Discussion}

MS patients without bone marrow involvement is a rare condition, accounting only for $1 \%^{2}$. MS can be involved in the lymph nodes, testes, skin, and soft tissues, but less frequently in the peritoneum or omentum ${ }^{3}$. Therefore, the diagnosis of MS is challenging due to the fact that cellular infiltrates are nonspecific, and the clinical manifestations are atypical. It should be differentiated from malignant 
Iymphoproliferative neoplasms, mesothelioma, or other solid tumor ${ }^{4}$. MS patients with ascites as the first symptom are extremely rare and reminds us it is always important to perform a pathological examination when encountering unexplained ascites.

\section{Acknowledgment}

The authors thank the staff in the Department of Pathology in Xiangya Hospital for their critical work.

\section{References}

1. Meireles LC, Lagos AC, Marques I, et al. Myeloid sarcoma of gastrointestinal tract: A rare cause of obstruction. Rev Esp Enferm Dig 2015;107:326-7.

2. Dores GM, Devesa SS, Curtis RE, et al. Acute leukemia incidence and patient survival among children and adults in the United States, 2001-2007. Blood 2012;119:34-43.

3. Goyal G, Bartley AC, Patnaik MM, et al. Clinical features and outcomes of extramedullary myeloid sarcoma in the United States: analysis using a national data set. Blood Cancer J 2017;7:e592.

4. Wilson CS, Medeiros LJ. Extramedullary Manifestations of Myeloid Neoplasms. Am J Clin Pathol 2015;144:219-39. 

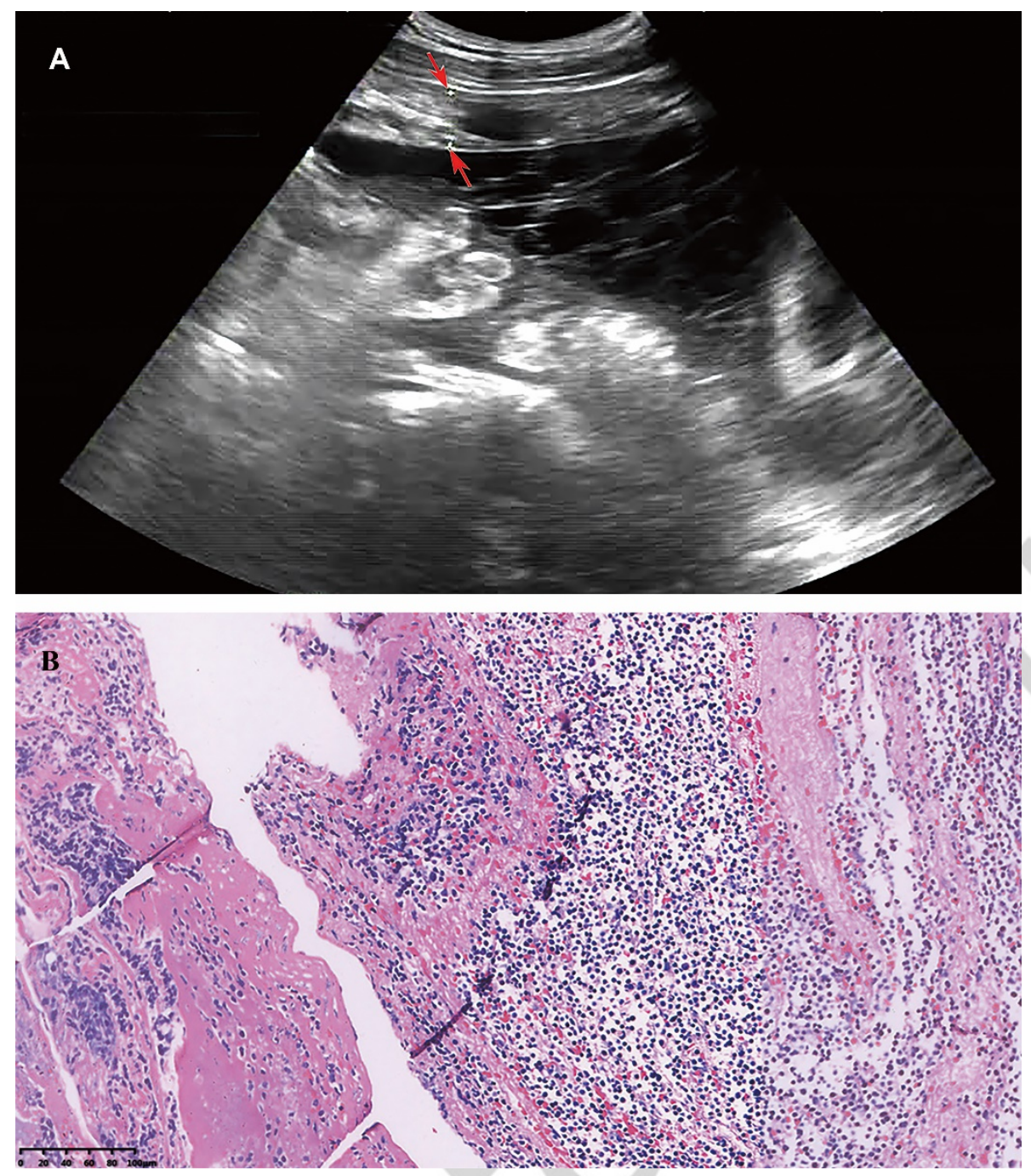

Figure 1. (A). Ultrasound showed an uneven thickening of the omentum with thickness of $22 \mathrm{~mm}$ (red arrow). (B) Ultrasound-guided biopsies revealed lots of granulocytic cells infiltration, which was suggestive of hematopoiesis disease, (hematoxylin and eosin $\times 400$ ). 